\title{
誘導型パルスパワー電源を用いた $\mathrm{NO}_{\mathrm{x}}$ 除去
}

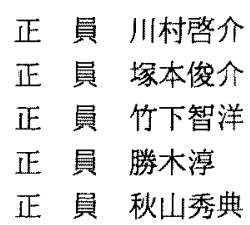

\author{
（三菱重工業） \\ (有明工業高等専門学校) \\ (熊本大学) \\ (熊本大学) \\ (熊本大学)
}

\author{
$\mathrm{NO}_{x}$ Removal using Inductive Pulsed Power Generator \\ Keisuke Kawamura, Member (Mitsubishi Heavy Industries, Ltd.) \\ Syunsuke Tsukamoto, Member (Ariake National College of Technology) \\ Tomohiro Takeshita, Member (Kyusyu Electric Power Co., Inc.) \\ Sunao Katsuki, Member, Hidenori Akiyama, Member (Kumamoto University)
}

\begin{abstract}
The discharge using pulse power with a short pulse width can produce a lot of electrons with high energy. This method has a possibility to remove poisonous gases with low energy consumption. In this paper, the inductive energy storage pulsed power generator, which can generate narrow and high voltage pulses (FWHM less than $100 \mathrm{~ns}$, output voltage of about $100 \mathrm{kV}$ ), is used to remove $\mathrm{NO}_{x}$ gas. It is found from spectrum measurement that this generator can produce high energy electrons, more than $10 \mathrm{eV}$, in the discharge region at atmospherics pressure. The mixed gases of $\mathrm{NO}$ and $\mathrm{N}_{2}$ are used as a trial gas. The NO removal ratio of about $95 \%$ is achieved without producing $\mathrm{NO}_{2}$. These chemical phenomena are approximately explained by solving rate equations.
\end{abstract}

$$
\text { キーワード: パルスパワー, 誘導性エネルギー蓄積方式, オープニングスイッチ,ストリーマ, } \mathrm{NO}_{\mathrm{x}}, \text { 排気ガス処理 }
$$

\section{1. まえがき}

産業革命以来, 人類は化石燃料を大量消費し，それに伴 い大気污染物質を大量に排出してきた。この排気ガス含ま れる窒素酸化物や硫黄酸化物による酸性雨で, 地球環境破 壞が全世界で進んでいる。これらの酸化物を軽減し地球環 境を守ることは我々の責務である。現在，日本では脱硫・ 脱硝技術が確立していて, 実用化されている。これは湿式 石灰石高法,アンモニア接触還元法によるもので設備の性 能は高く, 有用性と信頼性が実証されているが,これらの 装置は非常に巨大で高価である。そのためこれらの設備を 全世界に普及させることは困難であるため，小型化，低コ ス卜化が可能な排ガス処理技術が求められている。これら の問題を解決させるため, 放電によって生じる高エネル ギー電子を用いて有毒ガスを分解する研究が行われるよう になった。この方法を用いると乾式化の可能性があるため 装置の小型化につながり，将来有望な技術として注目され ている。

現在, 無声放電や高電圧 DC コロナ放電を用いて排気ガ スを処理する研究が行われているが, 消費電力が大きいこ とから実用化に至っていない(1)。ガスを分解するにはガス 分子の解離エネルギー以上のエネルギーを持つ多量の電子 が必要で，その值は $10 \mathrm{eV}$ 程度である。通常の大気圧放電 は $10 \mathrm{eV}$ を越える高エネルギ一電子を豊富に生成すること は難しいが，パルスストリーマ放電を用いると均一な放電
中に，高エネルギー電子を生成することが可能である。大 気圧中でストリーマ放電を発生させるためには, 印加電圧 の立ち上がりが速く，パルス幅を狭く，かつ高電圧化する ことが必要である。その理由は電圧 (電界) の立ち上がり が速ければ，アーク放電に転移する前の高インピーダンス 時に高い電圧を印加できるためであり，この高電界によっ て多量の高エネルギー電子の生成が可能となる。アーク放 電に転移すると，均一なプラズマを維持できないため放電 エネルギーに対する排気ガス処理効率が極端に悪くなる。

イタリア電力公社 ENEL は石炭火力発電ボイラの排気ガ スの一部を用いてパルスストリーマ放電による排気ガス処 理を行った(1)。これは単一の乾式プロセスで $\mathrm{NO}_{x}$ と $\mathrm{SO}_{2}$ を 同時に処理でき，既存の設備を利用できるようになってい る。パルス放電プラズマ ${ }^{(2)}$ ，無声放電 ${ }^{(3)}{ }^{(4)}$ ，無声放電と沿 面放電の複合 ${ }^{(5)}$ によって㗧素酸化物を除去する研究も行わ れている。また排気ガス中にフライアッシュがある場合の 除去効率への影響についての研究も行われている ${ }^{(6)}$ 。窒素 酸化物の分解ばかりでなく工業的化学反応で生じた危険な ガス $\left(\mathrm{C}_{7} \mathrm{H}_{8}, \mathrm{CH}_{2} \mathrm{CL}_{2}, \mathrm{CF}_{2} \mathrm{CL}_{2}-\right.$ Freon 12 等) を放電を用い て分解する研究も行われている(7)。これらの研究では，放 電を起こすための電源として, 主として容量型電源が用い られている。エネルギー転送時間が時定数 $R C$ で決まるの で, 放電抵抗が比較的大きく, かつ必要な蓄積エネルギー のもとで半值幅を数百ナノ秒と小さくすることが困難で あった。そのため排気ガス処理効率に難があるのが現状で 
ある。誘導性エネルギー蓄積方式パルスパワー電源は，イ ンダクタにエネルギーが蓄積されるため転送時間は時定数 L/Rで決定され，かつオーブニングスイッチの開放速度で 出力電圧およびパルス幅が決定されるので電圧の短パルス 化, 高電圧化が可能である ${ }^{(8)}$ 。

本研究では誘導型パルスパワー電源を用いてNO $\mathrm{N}_{\mathrm{x}}$ を分解 する実験を行った。この方式にはオープニングスイッチが 必要である。オープニングスイッチとして銅線溶断スイッ チ,プラズマオープニングスイッチ，プラズマフロース イッチ等があげられる(8)。パルス幅の短い高電圧を発生す るためには電流を高速に遮断しなければならない。そのた めオープニングスイッチとして取り扱いが容易で比較的高 速に電流を遮断できる銅線溶断スイッチを用いた。これま では銅線が直径 $0.03 \mathrm{~mm}$ と極めて細いので高絽り返しで動 作させることができなかったが, 今回は自動的に最大 $2 \mathrm{~Hz}$ で銅線を固定する装置を開発しこれを用いて実験を行っ た。はじめに電極間に誘導型パルスパワー電源により放電 を発生させた時に, どの程度の高エネルギー電子が生成さ れているかについて,分光学的手段を用いて測定を行った。 次に, 同じ電源を用いてストリーマ放電を発生させ, 実際 に模擬ガス（窒素希釈NOガス）を分解する実験を行った。 化学反応現象を説明するために, $\mathrm{NO}_{\mathrm{x}}$ 除去に関与する反応 式を選び，このレート方程式 (9) (10) を用いて計算機シミュ レーションを行い，実験結果と比較・検討した。

\section{2. 誘導型パルスパワー電源を用いたパルス放電特性}

<2.1> 誘㱏型パルスパワー電源 ${ }^{(8)} \quad$ パルスパワー発 生装置には電気的には容量性エネルギ一蓄積方式と誘導性エ ネルギー蓄積方式の 2 種類がある。前者はエネルギーをコン デンサに電界エネルギーとして蓄積するのに対して, 後者は エネルギーをインダクタに磁界エネルギーとして蓄積する。 このとき,誘導性のほうが容量性よりもエネルギ一密度が2 析ほど大きいため, 同じ出力に対して小型・軽量となる。本 研究では，取り扱いが簡単な銅線溶断スイッチを用いた。

図 1 に誘導型パルスバワー電源の回路を示す。まず充電 器 $\mathrm{E}$ より充電抵抗Rを通してコンデンサ $C$ を充電する。そ の後, トリガトロンギャップスイッチ ${ }^{(8)} \mathrm{S}_{1}$ を動作させ,

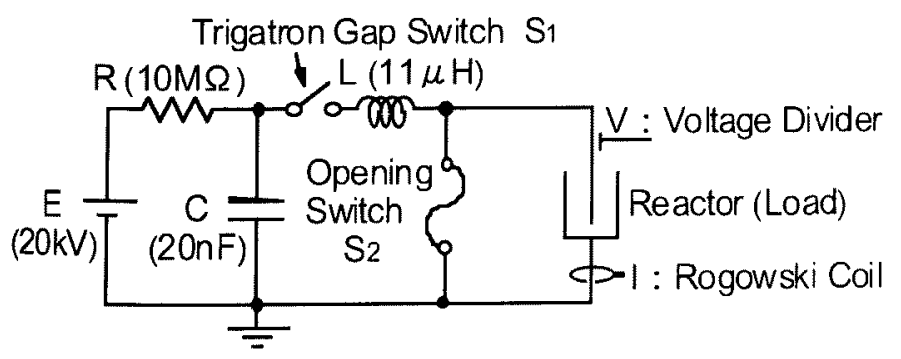

図 1 誘導型パルスパワー電源回路

Fig.1. Circuit of inductive pulsed power generator.
オープニングスイッチ $\mathrm{S}_{2} に$ 電流を流してインダクタしにエ ネルギーを蓄える。ジュール熱によってオープニングス イッチ $\mathrm{S}_{2}$ が急激に液化・気化してオープニング動作が起こ り,このときインダクタLの両端に誘導電圧 $L \cdot d i / a t か ゙$ 発生 し，これがReactor（負荷）に印加される。

<2.2>パルス放電特性 図1のReactorとして線対平 板電極を設置した。これに印加される電圧, 放電電流波形 （充電電圧 $20 \mathrm{kV}$ ) を図 2 に示す。負荷における電圧・電流 の半值幅がそれぞれ $100 \mathrm{~ns}, 50 \mathrm{~ns}$ 程度であり，極めて短 い間に現象が完了していることがわかる。図3に電流-電圧 特性を示す。電圧の上昇と共に電流值が上昇する正特性を 示しており，安定に放電が持続していることがわかる。図 4 に，その時の放電状態を示す。線対平板電極間全体にわ たってアークに転移することなくストリーマ状の放電がか なり均一についていることが確認できる。

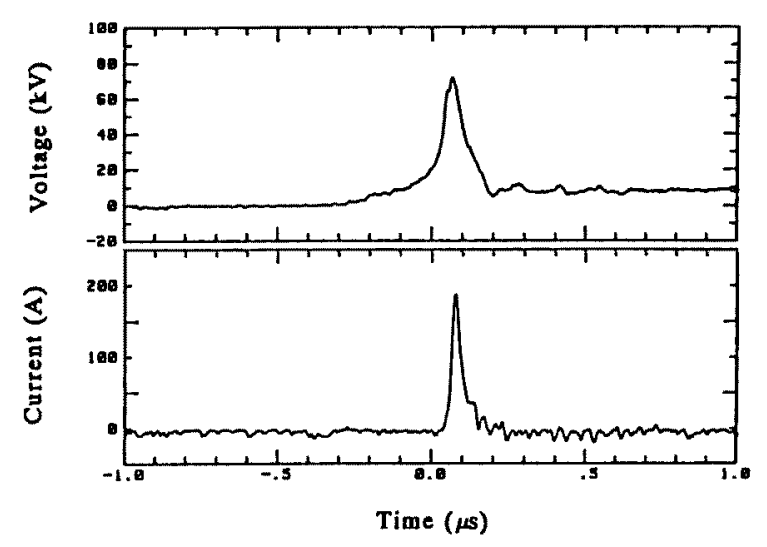

図 2 負荷への印加電圧, 放電電流波形

Fig.2. Waveforms of input voltage and discharge current.

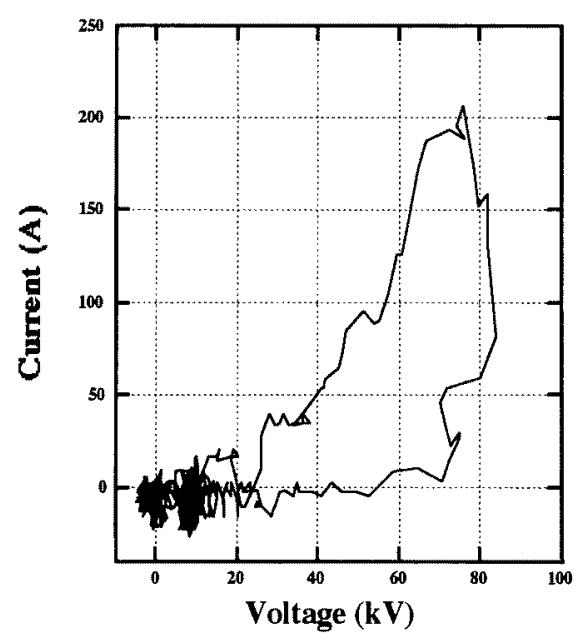

図 3 電圧 -電流特性

Fig.3. V-I characteristics. 


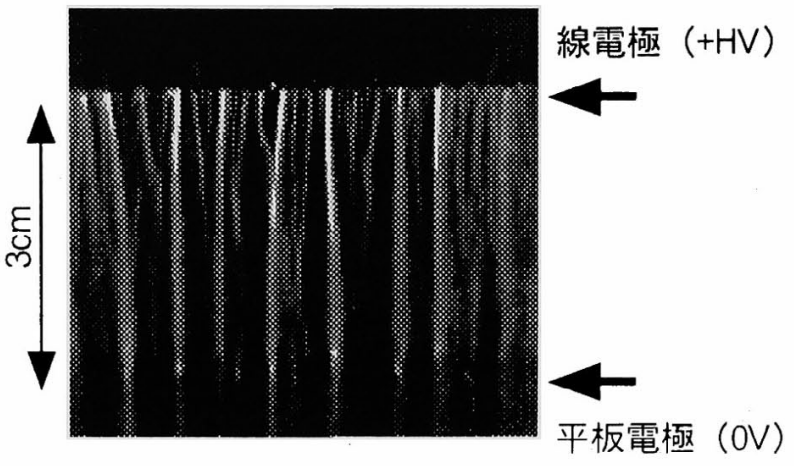

図 4 放電状態

Fig.4. Photograph of streamer discharge.

<2.3> パルス放電の分光計測 大気圧中で高エネル ギー電子を多量に生成するには, アーク放電に転移するこ となく, 高電界を印加し, 均一なストリーマ, またはグ ロー状放電をつけることが重要である。そこで分光器（モ ノクロメータ）を用いてパルス放電空間内の電子エネル ギー測定を行った。放電媒体は大気圧空気である。パルス 電界を印加したとき電界による電離によって生成された電 子が高速に加速されて高エネルギ一電子となり,これが空 気中の窒素分子に衝突して窒素分子が励起される。これが 下準位に遷移するときに放射する電磁波 2 nd positive band (337.1 nm, 閾値エネルギー $11.052 \mathrm{eV}$, 平均寿命約 $40 \mathrm{~ns}$ ) と, 1st negative band $(391.4 \mathrm{~nm}$, 閾值エネルギー $18.75 \mathrm{eV}$, 平均寿命約 $60 \mathrm{~ns}$ ) (11) の強度を測定した。これらの光強度 を測定することで, 放電によって発生される電子エネル ギーのおおよその値を知ることができる。

電子エネルギーを分光測定によって測定するために, 図 1 のReactorの部分に線（タングステン）対平板電極を用い

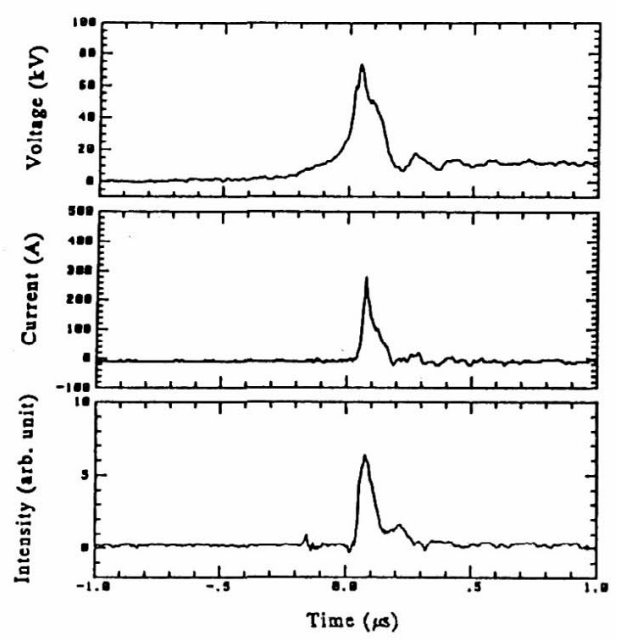

(a) 2nd Positive Band ( $337.1 \mathrm{~nm}, 11.052 \mathrm{eV}$ )
て実験を行った。線電極の直径を $1 \mathrm{~mm}$, 電極間隔を $30 \mathrm{~mm}$ に設定した。この間に誘導型パルスパワー電源からのパル ス電界が印加される。この時放電電極間に高エネルギー電 子が発生し, これによって励起した窒素分子が放射する光 を分光器で分光し, 光電子増倍管で増幅してオシロスコー プを用いて測定した。図 5 は2nd Positive Band (a), 1st Negative Band (b) からの光強度波形を示す。印加電圧と放 電電流波形も同時に示している。光強度波形は印加電圧波 形とほほ一致していて，上準位から下準位に遷移する寿命 が極めて短いことが分かる。図 6 に, 印加電圧と $2 n d$ Positive Band, 1st Negative Band の光強度の関係を示す。 光強度は印加電圧の増加とともに増加している。2nd positive bandの閾値エネルギーは $11.052 \mathrm{eV}$ なの゙，少な くとも $10 \mathrm{eV}$ 以上の高エネルギー電子が放電領域中に多量 に生成されていると考えられる。また光を急激に放出し始 める電圧は2nd Positive Band が約 21 kV, 1st Negative Band

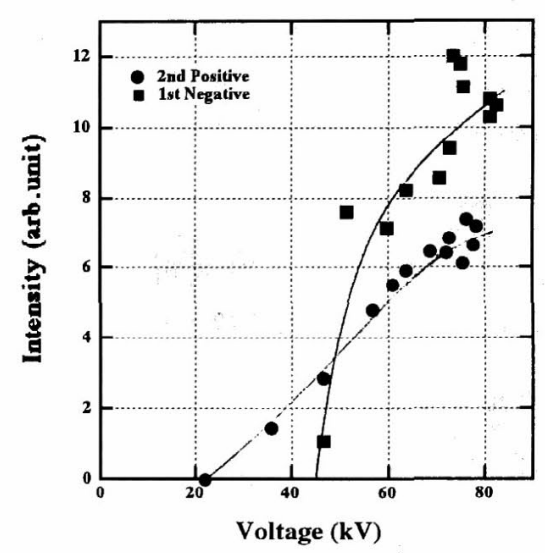

図 6 印加電圧と光強度の関係

Fig.6. Relation between input voltage and light intensity.

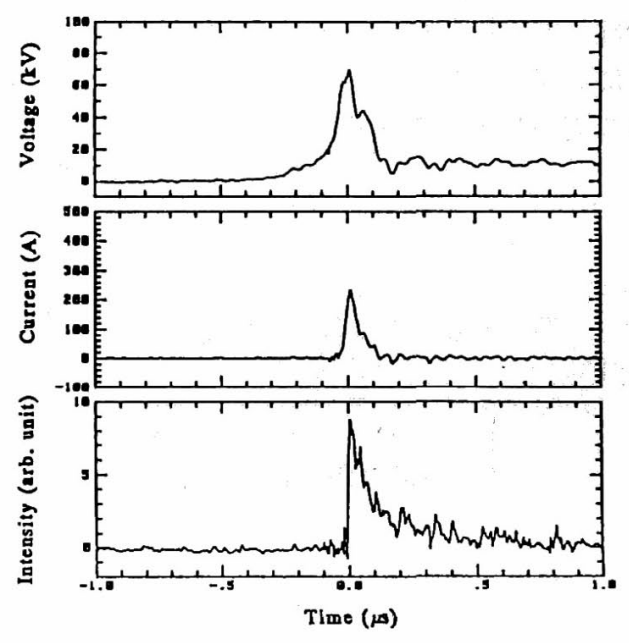

(b) 1st Negative Band (391.4 nm, $18.75 \mathrm{eV})$

図 5 印加電圧, 放電電流, 光強度波形

Fig.5. Waveforms of input voltage, discharge current and light intensity. 
が約 $45 \mathrm{kV}$ 付近である。この理由は間値エネルギーの大小 によるものであり，大気圧中に放電によって $10 \mathrm{eV}$ を越え るような高エネルギー電子を豊富に生成するには, 光強度 が增加し始める約 $20 \mathrm{kV} / \mathrm{cm}$ 以上の平均電界（印加電圧 $60 \mathrm{kV} /$ 電極間距離 $3 \mathrm{~cm}$ ) が必要であると考えられる。尚, 印加電圧 $70 \mathrm{kV}$ 付近の光強度のばらつきは, 主にショット 毎のストリーマ放電のばらつきに起因する。

\section{3 . 排ガス処理実験及び検討}

放電による排ガス処理は，放電領域にいかに効率よく、 かつ均一にエネルギーを注入し，しかもく3.2>で示すよ うにN $N_{2}$ を解離してNOを処理するたけの高エネルギ一電子 を生成できるかが実用化への鍵となる。ここでは，誘導型 パルスパワー電源を用いて模擬ガス $\left(\mathrm{N}_{2}\right.$ 希釈 NOガス) を 分解する実験を行った。

<3.1>実験装置と実験結果図 7 に排ガス処理系統を 示す。本実験では電源の高繰り返し化が困難だったこと, 及び単位体積当たりの注入エネルギーを大きくするために， ガスの流れを止めた状態で放電処理を行う，ガス詰め方式 を採用した。放電管の形状は図 8 のように線対円筒を用い た。内部電極はタングステン製で外径が $1 \mathrm{~mm}$, 有効長さ $500 \mathrm{~mm}$, 外部電極は銅製で内径が $76 \mathrm{~mm}$, 長さ $500 \mathrm{~mm}$ を用いた。ここでは模擬ガスとして $\mathrm{N}_{2}$ 希积NO (100 ppm) ガスを用い，この時のガス温度は室温（約 300 K）であっ た。この模擬ガスを放電管に詰め，これを誘導型バルスパ ワー電源による放電で処理し，その後 $\mathrm{N}_{2}$ 希釈 NOガスで押 し出してガス分析器（"Gas Analyzer Testo33" Testo Term Co.) でNO, $\mathrm{NO}_{2}$ の濃度变化を測定した。放電管に印加さ れる電圧は抵抗分压器 (高抵抗 $10 \mathrm{k} \Omega$, 低抵抗 $2 \Omega$ ), 放電 電流はロゴスキーコイル ("Model 110A" Pearson Electronics Inc.) を用いて，オシロスコープ (HP54512A) で モニターした。

充電電圧 $20 \mathrm{kV}$ 時の放電管（放電媒体： 1 気圧の $\mathrm{N}_{2}$ 希积 NOガス)に印加される典型的な電圧, 電流及び放電エネル ギー波形を図 9 に示す。放電エネルギ一波形は電圧と電流 の積を計算機で時間積分して算出した。その結果, 1ショッ 卜当たりの放電エネルギーは約 0.9 」であることがわかっ

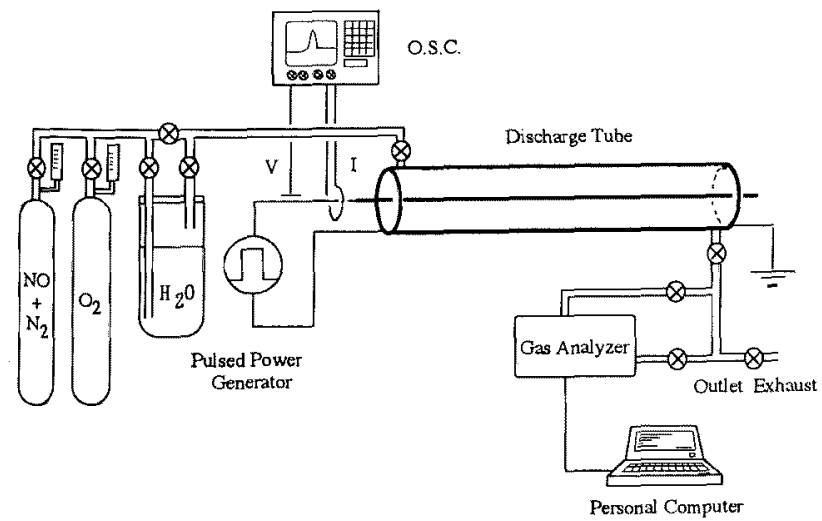

図 7 排ガス処理系統

Fig.7. Pollution control system.
た。印加電圧の半値幅 (FWHM) は約 100 ns で最大值は約 $60 \mathrm{kV}$, 電流の半值幅は約 $50 \mathrm{~ns}$ で最大值は約 $240 \mathrm{~A}$ となり, 極めて短い間に現象が起こっていることがわかる。図10に 横軸にショット数, 縦軸に $\mathrm{NO}, \mathrm{NO}_{\mathrm{x}}\left(=\mathrm{NO}+\mathrm{NO}_{2}\right)$ の除去率 を示す。除去率はNOの場合（NO初期濃度－NO 濃度）／ NO初期濃度 $\times 100$, NOx の場合（NOx 初期濃度 - NOx 濃 度) /NOx初期濃度 $\times 100$ 上り求めた。放電回数 200 回で $\mathrm{NO}_{x}$ 除去率 75\%，400回で95\%となった。この時 $\mathrm{NO}_{2}$ はほ とんど生成されなかったためNOは $\mathrm{N}_{2}$ と $\mathrm{O}_{2}$ に変換されたと 考えら机る。

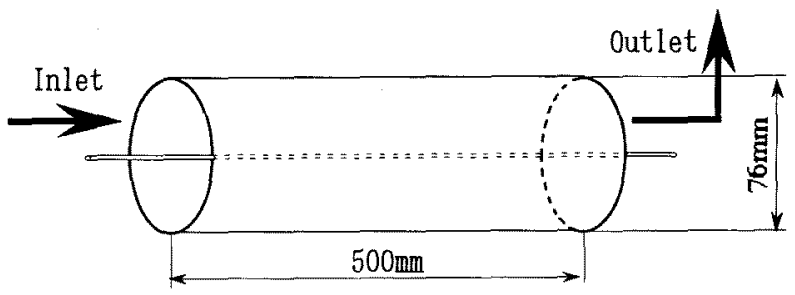

図 8 放電管形状

Fig.8. Geometry of discharge tube.

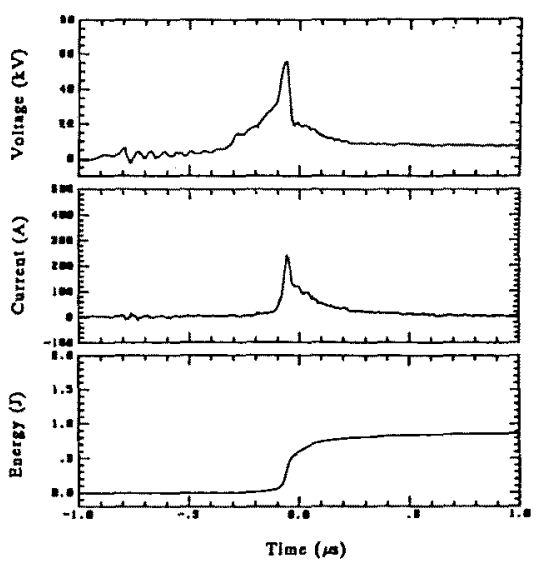

図 9 典型的な電圧, 電流, 放電エネルギー波形 Fig.9. Typical waveforms of voltage, current and discharge energy.

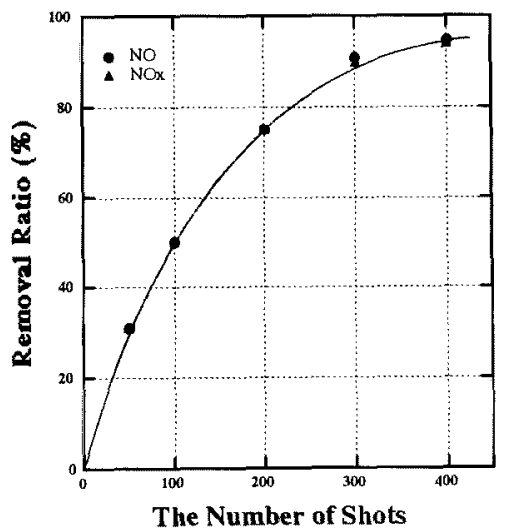

図10 NO, NO $\mathrm{x}$ の除去率

Fig.10. Removal ratio of $\mathrm{NO}$ and $\mathrm{NO}_{\mathrm{x}}$. 
<3.2> 化学反忘の解析及び実験結果の検討 $\mathrm{NO}_{2}$ を 生成せずにNOを分解する主な反応は $\mathrm{NO}+\mathrm{N} \rightarrow \mathrm{N}_{2}+\mathrm{O}$ であ るが，これと同時に NO+O+M (中性粒子) $\rightarrow \mathrm{NO}_{2}+\mathrm{M}$ の反 応で一時的に $\mathrm{NO}_{2}$ が生成される。しかしNO 2 を消費する反 応 $\mathrm{N}+\mathrm{NO}_{2} \rightarrow 2 \mathrm{NO}$ や $\mathrm{N}+\mathrm{O}+\mathrm{M} \rightarrow \mathrm{NO}+\mathrm{M}$ で逆に NO を生成 する反応も起きている。このようにNOは分解, 酸化反応 など様々な反応を繰り返し最終的に $\mathrm{N}_{2}$ と $\mathrm{O}_{2}$ に分解したと 考えられる。放電エネルギー（放電回数）の増加とともに 飽和傾向を示すのは, 放電エネルギーの増加とともにNO の濃度が減少し，NとOからNOを生成する反応が強くな るためであると考えられる。

放電後に起こる化学反応現象を更に詳しく説明するため にレート定数 (反応速度定数)，レート方程式 ${ }^{(9)(10)}$ を用い た計算機シミュレーションによって解析を行った。レート 方程式は原子, 分子, ラディカル, イオン等の種々の粒子 が互いに反応する速度を示す方程式で，その速度はレート 定数で決定される。実軻は室温（約 $300 \mathrm{~K}$ ) で行ったが, 既 知である 373 Kでのレート定数を用いて計算した。シミュ レーション手法として, 差分法を用いた。放電前のNOの 濃度は $100 \mathrm{ppm}$ とした。放電によって生成されるNとOの 原子数を求めるためには正確な電子エネルギー分布, 放電 体積，励起断面積等のパラメータが必要であるが，これら の正確な值の算出は現在のところ困難である。そのため 100 ショット時において計算值と実験值が一致する様にN と○の原子数を仮定した。その結果, パルスパワー放電 1 ショット (0.9 J) 当たり, NO 分子数の $4.5 \times 10^{-5} \%$ が N とOに， $\mathrm{N}_{2}$ 分子数の $4.5 \times 10.5 \%$ が NとNに解離すると仮 定すると 100 ショットにおける実験值と一致した。 $\mathrm{N}_{2}$ と NOの初期值はそれぞれ $2.69 \times 10^{19}$ molecule $/ \mathrm{cm}^{3}$ と 2.69 $\times 10^{15}$ molecule $/ \mathrm{cm}^{3}$ である。この場合, NOと比べて $\mathrm{N}_{2}$ の濃度が十分高いので $\mathrm{N}_{2}$ の解離が支配的になる。 $\mathrm{NO}_{x}$ 除去 に関与する化学反応式としては表 1 に示す $6 \supset$ の式を考 え,これらをもとにして,レート方程式をたてると以下の ようになる (9) (10)。

$$
\begin{aligned}
& \frac{\mathrm{d}[\mathrm{NO}]}{\mathrm{dt}}=-\mathrm{k}_{1}[\mathrm{NO}][\mathrm{O}][\mathrm{M}]-\mathrm{k}_{2}[\mathrm{NO}][\mathrm{N}]+2 \mathrm{k}_{3}[\mathrm{~N}]\left[\mathrm{NO}_{2}\right]+\mathrm{k}_{4}[\mathrm{O}]\left[\mathrm{NO}_{2}\right] \\
& \frac{\mathrm{d}\left[\mathrm{NO}_{2}\right]}{\mathrm{dt}}=\mathrm{k}_{1}\left[\mathrm{~N}[\mathrm{NO}][\mathrm{O}][\mathrm{M}]-\mathrm{k}_{3}[\mathrm{~N}]\left[\mathrm{NO}_{2}\right]-\mathrm{k}_{4}[\mathrm{O}]\left[\mathrm{NO}_{2}\right]\right. \\
& \frac{\mathrm{d}[\mathrm{O}]}{\mathrm{dt}}=-\mathrm{k}_{1}[\mathrm{NO}][\mathrm{O}][\mathrm{M}]+\mathrm{k}_{2}[\mathrm{NO}][\mathrm{N}]-\mathrm{k}_{4}[\mathrm{O}]\left[\mathrm{NO}_{2}\right]-\mathrm{k}_{5}[\mathrm{~N}][\mathrm{O}][\mathrm{M}] \\
& \frac{\mathrm{d}\left[\mathrm{N}_{2}\right]}{\mathrm{dt}}=\mathrm{k}_{2}[\mathrm{NO}][\mathrm{N}]+\mathrm{k}_{6}[\mathrm{~N}][\mathrm{N}][\mathrm{M}] \\
& \frac{\mathrm{d}[\mathrm{N}]}{\mathrm{dt}}=-\mathrm{k}_{2}[\mathrm{NO}][\mathrm{N}]-\mathrm{k}_{3}[\mathrm{~N}]\left[\mathrm{NO}_{2}\right]-\mathrm{k}_{2}[\mathrm{~N}][\mathrm{O}][\mathrm{M}]-2 \mathrm{k}_{6}[\mathrm{~N}][\mathrm{N}][\mathrm{M}] \\
& \frac{\mathrm{d}\left[\mathrm{O}_{2}\right]}{\mathrm{dt}}=\mathrm{k}_{4}[\mathrm{O}]\left[\mathrm{NO}_{2}\right]
\end{aligned}
$$

ここで［］は各粒子数（密度）を示す。四11にレート 方程式から求めた各ショット（50,100，200，400）後に おけるNO 分子数の時間変化を示す。パルス放電前の NO 分子の密度を初期値 0 とし, 減少量を負の值で表してい

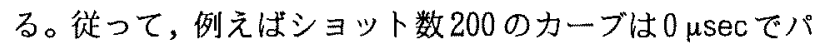

表 1 化学反応式に対するレート定数 (9) (10)

Table 1. Rate constants of chemical reactions.

\begin{tabular}{|c|c|}
\hline 化学庈応式 & $L-1$ 定数 \\
\hline $\mathrm{NO}+\mathrm{O}+\mathrm{M} \rightarrow \mathrm{NO}_{2}+\mathrm{M}$ & $\mathrm{k}:=6.3 \mathrm{E}-32 \mathrm{~b}$ \\
\hline $\mathrm{NO}+\mathrm{N} \rightarrow \mathrm{N}_{2}+\mathrm{O}$ & $\mathrm{k}=3.1 \mathrm{E}-11$ \\
\hline $\mathrm{N}+\mathrm{NO}_{2} \rightarrow 2 \mathrm{NO}$ & $\mathrm{k}=6.0 \mathrm{E}-13$ \\
\hline $\mathrm{O}+\mathrm{NO}_{2} \rightarrow \mathrm{NO}+\mathrm{O}_{2}$ & $\mathrm{k}=9.3 \mathrm{E}-12$ \\
\hline $\mathrm{N}+\mathrm{O}+\mathrm{M} \rightarrow \mathrm{NO}+\mathrm{M}$ & $\mathrm{k}=3.9 \mathrm{E}-32 \mathrm{~b}$ \\
\hline $2 \mathrm{~N}+\mathrm{M} \rightarrow \mathrm{N}_{2}+\mathrm{M}$ & $\mathrm{k}=3.9 \mathrm{E}-33 \mathrm{~b}$ \\
\hline
\end{tabular}

ルスパワー印加が終わり,その後化学反応によりNO分子 数が時間と共に変化する様子を示している。ショット数の 少ない 50,100 の場合においては残存 NO 分子数が $50 \mathrm{ppm}$ 以上と大きいため，パルス放電後急激に反応が起き，その 後緩やかに濃度が変化している。しかし400ショットでは NOの $90 \%$ 以上がすでに除去されて残存 NO 分子数が非常 に少ないため, NO分子数の変化はほとんどない。

図 12 に先に述べた $N O ， \mathrm{NO}_{\mathrm{x}}$ の除去シミュレーション結 果と図10の実験結果との比較を示す。実線と破線はNOと $\mathrm{NO}_{x}$ に対するシミュレーション結果を示す。実験結果とシ ミュレーション結果は良く一致し，このシミュレーション モデルがかなり妥当性を持つと考えられる。

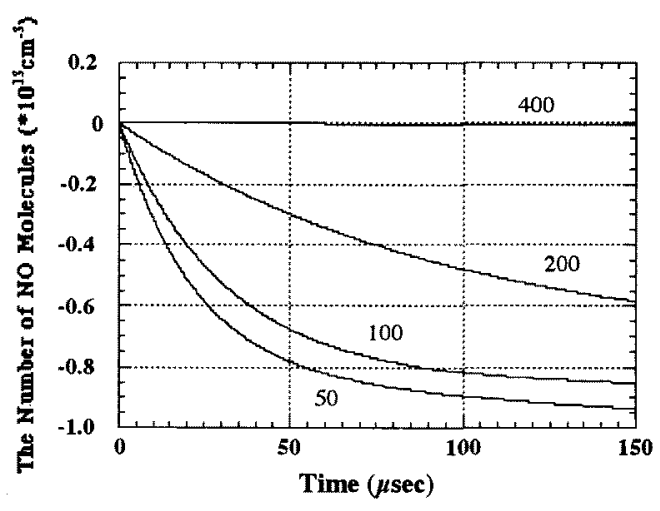

図 11 各ショット数におけるNO分子の時間的変化

Fig.11. Temporal changes of NO molecules on each shot.

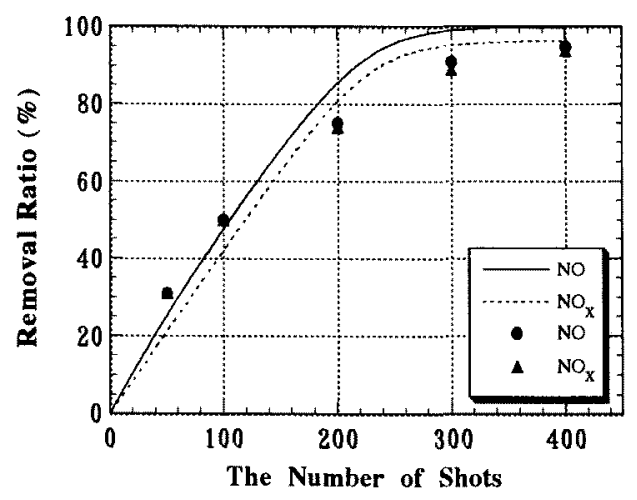

図 12 実験結果とシミュレーション結果の比較 Fig.12. Comparison of experimental results with simulated results 


\section{4.あとがき}

誘導型パルスパワー電源を用いると, 電圧のパルス幅が $100 \mathrm{~ns}$ と短いため一般の放電よりも高い電界を発生でき, この短パルス高電界が大気圧雾囲気において均一なス卜 リーマ放電の生成を可能にした。ストリーマ放電中の電子 エネルギーを検証するために分光計測を行った結果, 通常 の大気圧放電においては生成し難い $10 \mathrm{eV}$ 程度以上の高エ ネルギー電子をストリーマ放電中に多く生成できることが わかった。そこで模擬ガス $\left(\mathrm{NO}+\mathrm{N}_{2}\right)$ を用いて排気ガス処理 を行ったところ，ほとんど $\mathrm{NO}_{2}$ を生成することなく $\mathrm{NO} の$ $95 \%$ が $\mathrm{N}_{2}$ と $\mathrm{O}_{2}$ に変換された。またレート方程式を用いた 化学反応過程のシミュレーションを行った結果, 実験結果 とほぼ一致した。今後は処理効率向上実現のために更なる 高電圧化, 短パルス化及び電極形状の最適化を行う予定で ある。またNOx除去を促進させるためにアンモニア等の添 加物の選択等も考慮すべき課題である。計算機シミュレー ションに関しては, 各粒子の初期濃度の再検討, 中性分子・ 原子のみではなくイオンを含む化学反応を考虑に入れて再 度行う必要がある。

(平成 8 年 4 月 1 日受付, 平成 9 年 4 月 28 日再受付)

\section{文献}

(1) Giorgio Dinelli, Luigu Civitano and Massimo Rea, "Industrial Experiments on Pulse Corona Simultaneous Removal of $\mathrm{NO}_{x}$ and $\mathrm{SO}_{x}$ from Flue Gas, " IEEE Trans. Industry Application, vol. 26, no. 3, pp. 535-541, (1990)

(2) Senichi Masuda and Hideyuki Nakao, "Control of $\mathrm{NO}_{x}$ Positive and Negative Pulsed Corona Discharge, " IEEE Trans. Industry Application, vol. 26, no. 2, pp. 374-383, (1990)

(3) 相馬憲一 : 無声放電プラズマによる $\mathrm{NO} \rightarrow \mathrm{NO}_{2}$ 反応, 電 気学会プラズマ研究会資料, EP-94-67, pp. 21-28, (1994)

(4) 東學, 藤井寛一: 放電プラズマを用いた自動車排ガス処 理, 電気学会プラズマ研究会資料, EP-94-66, pp. 15-20, (1994)

(5) 宮本秀志, 伊藤泰郎：「NO ${ }_{x}$ の分解における放電重畕効 果」電学論 A, 116 巻 8 号, pp. 678-683, (1996)

(6) J. Sidneyclements, Akira Mizuno, Wright C. Finney RIGHT, and Robert $\mathrm{H}$. Davis, "Combined Removal of $\mathrm{SO}_{2}, \mathrm{NO}_{\mathrm{x}}$, and Fly Ash from Simulated Flue Gas Using Pulsed Streamer Corona, " IEEE Trans. Industry Application, vol.25, no.1, pp. 62-69, (1989)

(7) M. G. Grothas, R. K. Hutcherson, R. A. Korzekwa, and R. Roush, "Coaxial Pulsed Corona Reactor for Treatment of Hazardous Gases, " Proc. of 9th IEEE Pulsed Power Conf., vol.1, pp. 180-183, (1993)

(8) 原雅則, 秋山秀典 :「高電圧パルスパワー工学」, 森北 出版株式会社，(1991)

(9) James C. Person and David O. Ham, "Removal of $\mathrm{SO}_{2}$ and $\mathrm{NO}_{x}$ from Stack Gases by Electron Beam Iradiation, "Radiat.
Phys. Chem. , vol.31, pp. 1-8, (1988)

(10) R. P. Dahiya, S. K. Mishra, and A. Veefkind, " Plasma Chemical Investigation for $\mathrm{NO}_{x}$ and $\mathrm{SO}_{x}$ Removal from Flue Gases, "IEEE Trans. on Plasma Science, vol.21, no.3, pp. 346-348, (1989)

（11）金田輝男, 市川幸美, R. M. Hobson, J. S. Chang : 「電離気 体の原子・分子過程」, 東京電機大学出版局, (1982)

川村 啓介 (正員) 昭和 45 年 5 月 19 日生。平成 5 年

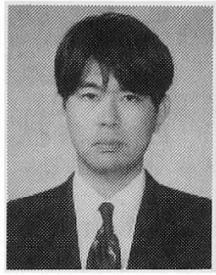
3 月熊本大学工学部電気情報工学科卒業。 平成 7 年 3 月同大学大学院工学研究科電気 情報工学専攻卒業。現在, 三菱重工業（株） に勤務。

塚本 俊介 (正員) 昭和 29 年 7 月 3 日生。昭和 50 年

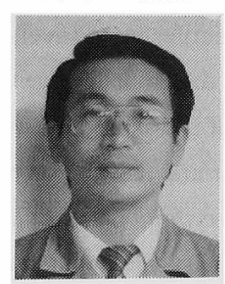
3 月有明工業高等専門学校電子工学科卒業。 同年 4 月国鉄九州総局入社, 昭和 61 年有 明工業高等専門学校文部技官, 平成 3 年 4 月同助手, 平成 5 年 4 月同講師, 現在に至 る。

竹下 智洋 (正員) 昭和 46 年 6 月 2 日生。平成 6 年 3

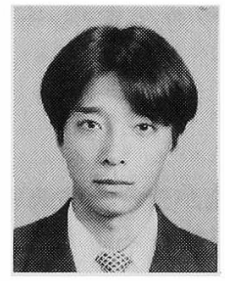
月熊本大学工学部電気情報工学科卒業。平 成 8 年 3 月同大学大学院工学研究科電気情 報工学専攻卒業。現在, 九州電力（株）に 勤務。

勝木 淳 (正員) 昭和 41 年 1 月 5 日生。平成 3 年 3

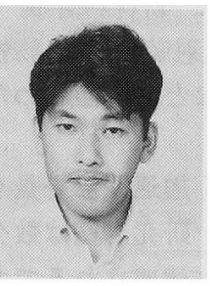
月熊本大学大学院修士課程修了。同年 4 月 同大学工学部助手, 現在に至る。日本物理 学会。

秋山 秀典 (正員) 昭和 26 年 4 月 2 日生。 54 年 3 月

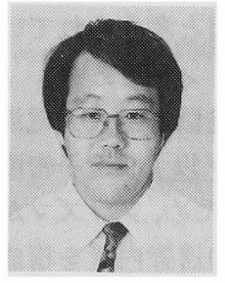
名古屋大学大学院博士課程修了。同年 4 月 同大学工学部助手, 60 年 4 月熊本大学工 学部助教授, 平成 6 年 8 月同教授, 現在に 至る。工学博士。日本物理学会, 日本レ一 ザ学会, プラズマ・核融合学会, IEEE会員。 